\title{
Reading Habits and Attitudes of UMSKAL Undergraduates
}

\author{
Shameem Ahmed \\ Centre for the Promotion of Knowledge \& Language Learning \\ University Malaysia Sabah-KAL, Malaysia \\ E-mail: shameem@ums.edu.my
}

Received: 23-09-2015

Accepted: 29-12-2015

Advance Access Published: January 2016

Published: 01-03-2016

doi:10.7575/aiac.ijalel.v.5n.2p.189 URL: http://dx.doi.org/10.7575/aiac.ijalel.v.5n.2p.189

\begin{abstract}
Effective reading is essential for success in acquiring a foreign language (Mikulecky 2008). Students have to read a wide range of textbooks and related materials at the tertiary level. Lack of adequate reading habit is, therefore, bound to impede students' progress towards mastery of a foreign language. This study investigated reading habits and attitudes on reading of the undergraduate students attending ESL courses at a public university in Malaysia. For data collection, a 35 item questionnaire based on the Adult Survey of Reading Attitude (ASRA) from the work of Smith (1991) were designed and administered on around 314 students. The questionnaire investigated the students' general habit, preferences, and attitude towards reading. This study was based on the following research questions: What are the reading habits of these undergraduate students? What are the attitudes of these students to reading as a useful language learning skill? What are the reading preferences of these undergraduate students? The research findings through qualitative analysis revealed that the undergraduate students had an overall positive attitude towards reading in spite of their minimal enjoyment of it and the resulting anxieties and difficulties they face. Based on the findings, few recommendations were made to improve reading among those undergraduates.
\end{abstract}

Keywords: Reading habits, attitude towards reading, reading preferences, ESL

\section{Introduction}

Tindale (2003) defines reading as a complex cognitive task, seen variously as being dependent on either: i. information processing/decoding skills (bottom-up skills); ii. background knowledge (top- down skills); iii. an interaction between bottom-up and top- down skills or; iv. a complex mix of top- down and bottom-up skills combined with social experiences (new literary approaches).

Reading plays a significant role in second/foreign language acquisition. It is much neglected by adult learners due to the predominant use of internet and different electric gadgets. Reading is an essential skill for learning of English as a foreign or second language. For the learners it is the most important skill to master in order to ensure success not only in learning English, but also in learning any content class where reading in English is required. With enhanced reading skill; learners will make better improvement and progress in all other areas of learning.

Undeniably, there are various reasons that teachers want their students to read English texts. Students need to read texts in English either for their occupations, for studies or for sheer fun and pleasure. Reading is useful for other purposes too as any exposure to English is a positive thing for language students. At least, some of the language sticks in their minds as part of the process of language acquisition, and, if the reading text is especially interesting and engaging, acquisition is likely to be even more successful. Moreover, reading texts also provide good models for English writing. Reading texts also provide opportunities to study language: vocabulary, grammar, punctuation, and the way sentences, paragraphs and texts are constructed. Furthermore, good reading texts can introduce interesting topics, stimulate discussion, excite imaginative responses and be the springboard for well-rounded, fascinating lessons. In any way if teachers can enable and motivate learners to read the task of teaching will be very much easier (Harmer, 1998).

Anderson (2012) opines that to make effective reading instruction, teachers can view reading as the core language skills and they should build the development of all language skills around effective reading instruction. This concept was represented in the following model:

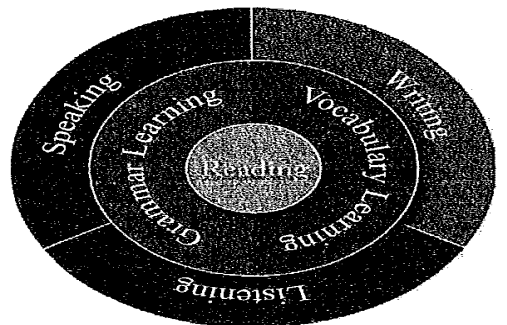

Placing reading at the core of language learning instruction 
Grabe (2009) addresses that citizens of modern societies must be good readers to be successful. Reading skills do not guarantee success for anyone, but success is much harder to come by without being a skilled reader. The electric communication only increases the need for effective reading skills and strategies as we try to cope up with the large quantities of information made available to us. A person's future opportunities for success and prosperity will be even more connected with skilled reading abilities. It is therefore an important societal responsibility to offer every person the opportunity to become a skilled reader, and in many cases, this means becoming a skilled L2 reader.

Wallace (2003) defines the purpose of reading as three fold: reading for survival, some kinds of reading in response to the environment; reading for learning as reading functions the broader role of encompassing our general knowledge of the world; and reading for pleasure, an important by-product of reading for pleasure in any language is fluency.

Reading competence and reading ability are used interchangeably with varied definition, but all come from the same basic assumption that successful comprehension occurs from the integrative collaboration of derived text information and preexisting reader knowledge. In other words, comprehension ensues when the reader extracts and integrates numerous facts and data from the text and combines it with what is already known. Each of these processes is generally used to define reading competence, though from diverse standpoints (Koda, 2008).

\section{Background}

English came into being in Malaysia during the seventeenth century when the British came and colonized the country. Their presence gave the English language pre-eminence in the government, business and social arenas (Ahmed, 2015). Since its independence, one of Malaysia's national developments was the increasing rate of literacy rate which became $50 \%$ in 1957 and rose to $80 \%$ by 1995 . There was a major paradigm shift when the government decided to make Malay as the medium of instructions in schools and colleges rather than English and today all Malaysian universities use Malay as the medium of instruction and English has become the second language (Pandian, 1997a).

According to the 1982 National Literacy Survey carried out by the National Library (cited in Inderjit, 2014), Malaysians only read an average of one to two pages a year. Another survey by the same institute in 1996 showed the reading habits among Malaysians have improved to two books per year. The last survey done in 2005 reported that the reading habits among the Malaysians are unchanged since they read an average of two books per year. A recent survey in 2006 by Malaysian National Library showed that the literacy rate has slightly decreased to $92 \%$ from $93 \%$ in 1996 .

In spite of the growing literacy rate, there was an emerging major problem needed urgent attention in the form of the increasing number of "reading reluctancy", i.e. "the phenomenon of adults and adolescents who can read but choose not to read". 80 percent of students in Malaysian universities are in the category of reluctant reader both in Malay and English. The major reasons for this problem are (a) a lack of positive role models in home and schools, (b) peer influence, and (c) the limited availability of reading materials at home and school. This serious issue was taken into consideration by the government with regards to the current state of major advancements in communication and technology (Pandian, 1997a).

Pandian (1999) further contends that reading as an activity is fast losing its appeal as other forms and types of media overtake and predominate. Consequently, the widespread use of different social medias like Facebook, Twitter, Pinterest, Google Plus ${ }^{+}$etc. in the internet, and smartphones and such other electric gadgets have tremendously overshadowed reading as an activity not only as fun but also as a very important skill in gaining command over a second or foreign language. Rather, these new and popular Medias have not only surpassed traditional modes of reading but have also cultivated a general idea that reading is fundamentally monotonous and uninteresting activity.

Mullai (2001) informs that roughly five key factors affect reading in the schools in Malaysia: the education system, instructional methods, teacher beliefs and attitudes, instructional materials, and student attitude and mind-set. These factors have their focus on the attainment of information or the product at the cost of process. This has led to the expansion of a literacy that is more of a simplistic notion of literally knowing how to read and write than beyond that.

In this context, Mustapha (1995, p. 28 as cited in Sidek 2011) mentions that at the tertiary level, "many of the so-called 'fluent' readers are still incapable of reading for comprehension. The problems become more prominent when they have to read for information and without the teacher close at hand to teach them". According to Sidek (2011), this indicates that the Malaysian students at the tertiary level are not self-regulated readers, a perquisite for successful academic reading activities.

Pandian (1997a) suggests that parents and teachers have a crucial role to play as role models for building reading habits for the adolescents. He recommends several efforts to reduce reading reluctancy through readership promotion campaigns, book fairs, and further research on reading habits.

Another important factor should be taken into consideration is that the learning and teaching of ESL reading skills should be done in a more appropriate and practical way suggested by Mullai (2001) and Sidek (2011). In this context, Mullai (2001) contends that at the tertiary level reading is taught through discreet skills or sub-skills like skimming, scanning, finding main points, generalizing, inferring, and many other ways. Although many teachers may believe that these are reading strategies, Brown, Armbruster and Baker (1985 as cited in Mullai, 2001) argue that metacognition plays a dynamic role in reading and strategies, therefore, any effective reading must contain a discussion of metacognitive knowledge, skills and their implications. The Longman Dictionary of Applied Linguistics and Language Teaching (2010: 361) defines metacognitive knowledge or metacognition as “... knowledge of the mental processes which are involved in different kinds of learning. Learners are said to be capable of becoming aware of their own 
mental processes. This includes recognizing which kinds of learning tasks cause difficulty, which approaches to remembering information work better than others, and how to solve different kinds of problems. Metacognitive knowledge is thought to influence the kinds of learning strategies learners choose". English (2011) adds that various cognitive strategies may help learners to identify, change and manipulate the language. Metacognitive strategies employed by learners to self-monitor, plan and execute their own learning style may help to a great extent in ESL reading.

Guthrie \& Wigfield (2000) suggest that the ESL students' should be provided with as much motivation in reading as possible and when they have a helpful teacher and a sense of belonging in the classroom, they are more motivated for reading. Also in the form of giving rewards and positive incentive for book reading may increase the time and effort in book reading activities among these students.

Don and Osman (1987) suggest developing a positive attitude towards reading among the undergraduates through: reading games, leisure reading programmes, and sustained silent reading/study as part of the course activity along with other methods such as identification, through rewards, through successful experiences, through adapting to student's individual needs in reading, and through habit building. They also advocate activities like book fairs, book clubs and book promotions in various ways that the universities could consider from time to time for these undergraduate ESL learners.

\subsection{Study Objectives}

This study was based on the following research questions:

i) What are the reading habits of these undergraduate students?

ii) What are the attitudes of these students to reading as a useful language learning skill?

iii) What are the reading preferences of these undergraduate students?

\subsection{Literature Review}

The Longman Dictionary of Applied Linguistics and Language Teaching (2010: 258) defines habit as "a pattern of behaviour that is regular and which has become almost automatic as a result of repetition. The view of language learning as habit formation found in behaviourism has been rejected by virtually all linguists and specialists in language acquisition, but research continues into issues such as the mechanisms through which automaticity develops in language learning". It can be defined as the frequency of how often a learner develops an activity that enables him/her to read materials fiction, stories, magazines, newspapers etc. A good reading habit can enhance knowledge and the ability to use the target language more effectively.

Grabe and Stoller (2013) comment that "Students bring different attitudes about reading to the classroom; these attitudes influence students' motivation to involve themselves in reading lessons and related activities. Students' attitude to reading are often linked to previous experiences with reading, their exposure people who read and their perceptions about the usefulness of reading. An understanding of the students' attitudes can help us structure our lessons and the feedback that we give to individual students".

Baker (1988 as cited in Murray \& Christison 2010:175) outlines some important considerations on attitudes for language teachers: 1. Attitudes can be modified by experience; 2 . Once attitudes have been set, they tend to persist; 3 . Attitudes are not inherited; they are learned; 4. People are predisposed to act in certain ways depending on their attitudes, but the connection between actions and attitudes is not solid; 5. Humans can think about their attitudes, so they are cognitive; and also affective since our feelings are attached to our attitudes; 6 . Attitudes vary in continuum, so they vary in degree and strength. A slight change in attitude may move it from negative to positive;

A Dictionary of Linguistics and Phonetics (2008: 266) defines language attitudes as "a term used in sociolinguistics for the feelings people have about their own language or the language(s) of others. These may be positive or negative: someone may particularly value a foreign language (e.g. because of its literary history) or think that a language is especially difficult to learn (e.g. because the script is off-putting). ... Knowing about attitudes is an important aspect of evaluating the likely success of a language teaching programme or a piece of language planning."

Mokhtari and Sheorey (1994) led a study on reading habits of 85 under-graduate students at a comprehensive midwestern university in USA. The results showed that these students spent an unusually low amount of time on academic and even less amount of time on non-academic reading. There was no significant difference between the high and low proficiency that spent the amount of time spent in reading academic and non-academic materials. In a similar kind of study, Mokhtari et.al (2009), conducted another research on the impact of internet and television use on the reading habits and practices among 539 undergraduate students at a midwestern university in USA. The result showed that majority of the students enjoys using internet more than recreational reading, reading for academic purposes, or watching television.

Akarsu and Dariyemez (2014) explored the reading habits of 76 undergraduate students of English language and literature at Ataturk University, Turkey. The findings showed that the reading habits of the students were affected by the media and technology and majority of them stated that they often followed online information.

Akanda et.al (2013) investigated the reading habits of 260 postgraduate students at Rajshahi University, Bangladesh. The survey findings showed that the students read books and other materials with a sense of purpose and with specific target. Their main source of reading is the textbooks and the amount of time spent on reading is minimal as they are mainly affected by the emerging technologies, especially the internet, smartphones and TV-based entertainment. 
Jadal (2013) studied the reading habits of 100 B.Ed. students at University of Solapur, India. The study found that majority of the students does not have adequate reading habits and spend only one to two hours per day for reading. They generally read fictional writing and such other materials than the textbooks. These students have showed preference to general, case studies, economic and HR books and they least prefer reading in global issues and business.

Bendriss and Golkowska (2011) piloted a study on the early reading habits and its impact on the reading literacy of 72 Qatari undergraduate students. The research found links between reading extensively and confidence in reading, between being read to and forming the habit of free voluntary reading, and between parental recreational reading and that of their children. A surprising discovery of the data showed that extensive reading was encouraged more at home than at school.

A good number of researches have been done on the habit, attitudes, and interests of graduate/undergraduate students at educational institutes in Malaysia.

Noor (2011) examined 52 post-graduate students at UKM and their reading habits and preferences. She found that the students read various types of reading materials, have different reasons for reading as well as language preference in reading. Students primarily prefer online reading materials. In a similar vein, Karim et.al (2007) led a correlation study between the reading habits and attitudes vs. gender and academic programme among 127 undergraduate students at International Islamic University Malaysia. The study found that these undergraduates tend to use the web sites in an ever increasing number for important reading source. The respondents' attitude towards reading is positive and they agree that reading is an enjoyable activity.

Ismail and Elias (2009) investigated the reading habits and attitudes of 300 Part One Diploma students at MARA University of Technology Malaysia, Johor. They found that majority of the students have a positive attitude towards reading, but are reluctant readers of English materials or resources related to only to their studies. Susana and Mathai (2003) led a similar study on reading attitudes of 250 students at University Technology Mara, Penang. The Students were aware of the importance of reading but it was not a priority among them. Their reading attitudes in English are mainly intensive and due to lack of time they couldn't manage to read extensively.

Kwong et.al. (2005) conducted a study on reading habits of 402 undergraduate students at University Technology MARA, Perlis. The finding showed that majority of the students read newspapers and family background played a very important role in encouraging students to read. It was also found in the study that students with higher MUET bands tend to read more reading materials than students with lower MUET bands.

Subashini and Balakrishnan (2013) conducted a survey on the reading habits and attitudes of 119 students in a Malaysian Polytechnic. The result revealed that these students have low interest in reading and they do not enjoy reading as much as they prefer doing other technology related activities.

The current study was undertaken to estimate these undergraduate students' habits, attitudes and preference towards ESL reading in a Malaysian context. While data were analyzed and interpreted, the findings of the above reviewed studied both in Malaysia and other countries were taken into consideration and cross-checked to gauge out various aspects of this current study to get a better picture and understanding.

\section{Methodology}

This study was conducted and based on quantitative and qualitative approach of data analysis. Actually, the data were analysed mainly in a qualitative way with an interpretive approach. Qualitative research is concerned with qualitative phenomenon, i.e., events relating to or involving quality or kind. For instance, while investigating the reasons for human behaviour, we tend to deal with research on motivation. This type of research divulge into discovering the underlying motives and desires using in-depth interviews for this purpose. Researches such as attitude and opinion are designed to find out how people feel or what they think about a particular subject or institution is also qualitative research. Qualitative research is specifically plays significant role in the behavioural sciences where the objective is to discover the underlining motives of human behaviour. This type of research analyses the various factors which motivates people to behave in a particular manner or which make people like or dislike a particular thing (Kumar, 2008, p.8 as cited in Ahmed, 2015).

The questionnaire survey is one of the most common methods of data collection on attitudes and opinions from a large group of participation. It has been used to investigate a wide variety of questions in L2 research. Questionnaires allow researchers to gather information that learners are able to report about themselves that is typically not available from production data alone. One of the primary advantages of using questionnaires is that, apart from being economical and practical, they can in many cases bring about longitudinal information from learners in a short period of time. Questionnaires can also collect comparable information from a number of respondents. In addition, questionnaires can be administered in many forms, such as via e-mail, by phone, through mail-in-forms, as well as in person, allowing the researcher a greater degree of flexibility in the data collecting process. Based on the structure, questionnaires can provide both qualitative insights and quantifiable data, and thus are very flexible for use in a range of research (Macky \& Gass, 2005 as cited in Ahmed, 2015).

According to Dörnyei \& Taguchi (2010 as cited in Ahmed, 2015), questionnaires are one of the most common methods of data collection in L2 research. Questionnaires are very popular since they are easy to construct, extremely versatile, capable of gathering a large amount of information quickly in such a way that is readily processable. According to Brown, (2001, p. 6, cited in Macky \& Gass, 2005, as cited in Ahmed, 2015), "Questionnaires are any written 
instruments that present respondents with a series of questions or statements to which they are to react either by writing out their answers or selecting from among existing answers." Brown (2001, p. 2, cited in McKay, 2006, as cited in Ahmed, 2015) opines that language surveys are any studies "that gather data on the characteristics and views of informants about the nature of language or language learning through the use of oral interviews or written questionnaires".

Dornyei (2003, cited in McKay 2006, as cited in Ahmed, 2015) points out that survey can provide three types of information: (i) factual information; (ii) behavioural information; and (iii) attitudinal information. Surveys also act as a very useful tool for researchers to gather a good deal of information in a short time with little cost. As a result, surveys are a particularly effective way for teachers to find out more about the background, habits, and preferences of their students and this kind of information can be used in curriculum development.

This current study employed a questionnaire to collect data on students' points of view regarding their habits and attitude towards reading while learning English as a second at the university. The data of this study were collected through a questionnaire survey. The questionnaire survey method was preferred since this is suitable for practicality; data is easily measurable; easily accessible and flexible; and it is very economical, quick and effective. While preparing the questionnaire, special care was given to ensure standard and quality of the questions as well as the reliability, clarity, practicality and administerability of the instruments.

For this study, a semi-structured interview was also employed along with the questionnaire, since it was convenient for the interviewees to express their views and feelings. In this sense, the advantage of this type of interview is commonly acknowledged. In fact, this approach can be very effective in encouraging the interviewees to respond freely and does not restrict or constraint their responses. Nunan (1992:150) states that the semi-structured interview, mainly, “... gives the interviewee a degree of power and control over the course of the interview" and "the interviewer a great deal of flexibility". It was designed in order to obtain richer data, personalized responses, and further clarification regarding students' responses provided in the questionnaire.

Each interview took approximately 5-10 minutes. They were held before and after classes. The interviewed students were picked randomly from each section during Semester 2 Session 2013-2014, Semester 1 and 2 Session 2014-2015. With respect to recording what is being said, the main options are note-taking and questionnaire filling with some advantages and disadvantages. Note-taking is problematic as it requires that everything is written down quickly. As a solution, it was decided to take notes, using abbreviations and key words. As Nunan (1992) acknowledges, pen questions result in richer data but are much difficult to quantify. He suggests, however, to conduct "key word analysis". This consists in grouping the responses according to categories that can be noted through all the interviews. According to McDonough \& McDonough (1997:186-7) "the more open ended, exploratory and ethnographic interviews ... may be analysed qualitatively by searching for themes, by looking for patterns, by looking for interpretations which are consistent with all the information revealed in the interview." The raw data gathered from the questionnaire, and the semi-structured interview with the students and their comments were noted, and analysed by means of descriptive statistics such as tables, frequencies and percentages.

\subsection{Material}

This study produced qualitative and quantitative data through questionnaire. The data was analyzed mainly qualitatively through interpretive approach. As Tavakoli (2012: 505) contends "qualitative research is fundamentally interpretive, which means that the research outcome is ultimately the product of the researcher's subjective interpretation of the data. Several alternative interpretations are possible for each data set, and because qualitative studies utilize relatively limited standardized instrumentation or analytical procedures, in the end it is the researcher who will choose from them. The researcher is essentially the main measurement device in the study. Accordingly, in qualitative research, the researcher's own values, personal history, and position on characteristics such as gender, culture, class, and age become integral part of the inquiry."

Averages were calculated from a scale of 5-1 (i.e. 5=Strongly Agree, 4=Agree, 3=Uncertain, 2=Disagree, 1= Strongly Disagree). The survey questionnaire consisted of 35 items of questions. Out of these 29 items adopted from Smith's (1991) Adult Survey of Reading Attitude (ASRA) questionnaire were used in this study to measure the way these undergraduates 'feel about reading'. These 29 items in the questionnaire were very suitable and convenient for this present study. The first six close-ended questions were set to measure the learners' various reading habits and preferences in English. Questions from number 7 to 35 are direct questions regarding the learners' attitudes and preferences in reading. A total of 330 questionnaires were distributed among the undergraduate students during the Semester 2 Session 2013-2014, Semester 1 and 2 Session 2014-2015 at University Malaysia Sabah, KAL, Labuan, Malaysia. A number of 16 questionnaires were rejected due to incomplete and incorrect responses.

\subsection{Limitations}

This study is limited to one public university in Labuan, Malaysia, therefore, provides only a partial picture of the frame of mind of adult learners' attitude towards learning English as a non-major subject. It is assumed that students answered the questions honestly and sincerely. This current study was done with the hope that a much comprehensive research would be undertaken in the future to shade more light in this specific area. 
A total number of 314 students (male 62 and female 252) from Universiti Malaysia Sabah, Labuan International Campus, participated in the study. They were $1^{\text {st }}$ and $2^{\text {nd }}$ year students aged around 19-25 years (Malay 253 and Chinese/International 61). Most of them have studied English language around 10 years. Out of these 314 students, 253 took MUET (Malaysian University English Test) test and their average bands were: 17 got band 1;225 got band 2; 7 got band 3; and 4 got band 4 . The remaining 61 students had no such score as they were international students who came mainly from mainland China. The participating undergraduate learners at the Labuan International Campus were studying in Business and Information Technology courses majoring in International Finance, International Marketing, International and Offshore Banking, International Financial Economics, Islamic Finance, Multimedia Technology and E-Commerce etc. The above demographic information shows that these undergraduate learners have come from different cultural, educational background and was of mediocre level learners who had difficulties in coping up with various academic texts as was observed and presumed by the current researcher in the classroom environment. Furthermore, even though the majority of these learners were female, the gender of these undergraduates was not a decisive factor in this study.

\subsection{Instrument}

This study employed a questionnaire to collect data on the points of views of students about their reading habits and attitudes towards reading. The survey questionnaire was based on the Adult Survey of Reading Attitude (ASRA) from the work of Smith (1991) with some minor modification. The purpose of this study was to analyses the undergraduate students' habits and attitude towards reading as an essential skills in learning English taught at the tertiary level. For this purpose, a 35 items questionnaire was set. The participants of the study were 314 students: 62 males (19.7\%) and 252 females $(80.3 \%)$.

The questionnaire was composed of three sections. The first section requested background information such as age, gender, nationality, educational background, number of years studying English, and MUET band score. The second section of the questionnaire consisted of 6 items mainly close-ended questions related to the participants various reading habits and preferences. The third section consisted of 29 items using a 5-1 likert scale (11 items on activity of reading, 9 items on enjoyment of reading, and 9 items on anxiety and difficulty in reading) to measure out the students' attitudes and preferences towards reading.

\subsection{Data Analysis}

This study produced qualitative and quantitative data through questionnaires. Averages were calculated from a scale of 5-1 (5=Strongly Agree, 4=Agree, 3=Uncertain, 2=Disagree, 1= Strongly Disagree) and also through frequencies and percentage in the questionnaires for each item to describe the overall picture of how the students expressed their habits, preferences and attitudes towards reading while learning English as a second/foreign language.

\section{Findings and Discussions}

\subsection{Reading Habits and Preferences}

According to the APA Dictionary of Psychology (2015: 479) habit means "a well-learned behaviour or automatic sequence of behaviours that is relatively situation specific and over time has become motorically reflexive and independent of motivational or cognitive influence - that is, it is performed with little or no conscious intent."

APA Dictionary of Psychology defines preference as "1. in conditioning, the probability of occurrence of one of two or more concurrently available responses, usually expressed as either a relative frequency (compared to the frequency of all the measured responses) or a ratio. 2. more generally, the act of choosing one alternative over others" (2015: 821).

Findings on reading habits of the undergraduates were analyzed through their leisure time activities, amount of time spent on reading per day, types of reading materials read, hours spent on reading e-books and e-magazines per day and frequency of reading a book/novel last year.

Table 1 illustrates the distribution of five types of spare time activities with an option, i.e. computer games, surf net, watch television, sports, read and others. Majority of the students surf net (38.9). This is followed by watch television (17.2), sports (16.6), computer games (14.9), reading (12.4). The results pointed out that these students mostly use internet and watch television more rather that they read.

Table 1. Leisure time activities

\begin{tabular}{lcc}
\hline $\begin{array}{l}\text { Leisure time } \\
\text { activities }\end{array}$ & $\begin{array}{c}\text { No. of } \\
\text { respondents }\end{array}$ & $\begin{array}{c}\text { Percentage } \\
(\%)\end{array}$ \\
\hline surf net & 122 & 38.9 \\
\hline watch television & 54 & 17.2 \\
\hline sports & 52 & 16.6 \\
\hline computer games & 47 & 14.9 \\
\hline reading & 39 & 12.4 \\
\hline
\end{tabular}

Table 2. Shows the distribution of amount of time spent on reading per day by these students. 


\begin{tabular}{lcc}
\hline \multicolumn{1}{l}{ Table 2. Amount of time spent on reading per day } & $\begin{array}{c}\text { No. of } \\
\text { respondents }\end{array}$ & $\begin{array}{c}\text { Percentage } \\
(\%)\end{array}$ \\
\hline Less than 1 hour & 42 & 13.4 \\
\hline 1 to 2 hours & 184 & 58.6 \\
\hline 2 to 3 hours & 52 & 16.6 \\
\hline 3 to 4 hours & 21 & 6.7 \\
\hline More than 4 hours & 15 & 4.8 \\
\hline
\end{tabular}

Table 2 shows the distribution of amount of time spent on reading per day by the respondents. The result indicates that these undergraduate students spent a substantial amount of time on reading per day. A total of $58.6 \%$ of the students read between one to two hours per day. This result is somewhat expected due to academic activities that require a considerable amount of reading time in order to perform academically. However, the amount of time spent on reading should be attributed to reading academic books rather than other materials such as newspapers or fictions. The result is slightly higher than the study conducted by Mokhtari and Sheorey (1994) on university in the USA, where the average reading time per week was 4.75 hours.

Table 3. Types of reading materials read

\begin{tabular}{lcc}
\hline \multicolumn{1}{c}{ Reading material } & $\begin{array}{c}\text { No. of } \\
\text { respondents }\end{array}$ & $\begin{array}{c}\text { Percentage } \\
(\%)\end{array}$ \\
\hline $\begin{array}{l}\text { Online e-books and } \\
\text { journals etc. }\end{array}$ & 107 & 34.1 \\
\hline Textbooks & 57 & 18.2 \\
\hline Comics & 54 & 17.2 \\
\hline Magazines & 52 & 16.6 \\
\hline Newspapers & 44 & 14.0 \\
\hline
\end{tabular}

Table 3 shows the distribution of types of reading materials used by the respondents per day. The result indicates that these undergraduate students used various types of reading materials for reading purposes per day. A total of $34.1 \%$ of the students read online e-books and journals etc. This is followed by textbooks $(18.2 \%)$, comics $(17.2 \%)$, magazines $(16.6 \%)$, and newspapers $(14.0 \%)$. The results pointed out that these students mostly use online materials that they read.

Table 4 shows the distribution of the respondents preferred language used while engaged in reading per day. This study showed that majority of the students $(62.7 \%)$ prefer to read in Malay rather than in any other languages. This fact is quite understandable since majority of the respondents are native $(80.5 \%)$ speakers and the medium of instruction is Malay. The following $18.8 \%$ use Chinese and English was used by $18.5 \%$ of the respondents while using various reading materials per day.

Table 4. Preferred language for reading

\begin{tabular}{lcc}
\hline \multicolumn{1}{c}{ Language } & $\begin{array}{c}\text { No. of } \\
\text { respondents }\end{array}$ & $\begin{array}{c}\text { Percentage } \\
(\%)\end{array}$ \\
\hline Malay & 197 & 62.7 \\
\hline Chinese & 59 & 18.8 \\
\hline English & 58 & 18.5 \\
\hline Others & 0 & 0.0 \\
\hline
\end{tabular}

Table 5 shows the distribution of amount of time spent on surfing internet per day by the respondents. This study showed that majority of the undergraduates spent a significant amount of time surfing the internet per day. A total of $57.6 \%$ use internet between one to two hours per day, meanwhile $10.8 \%$ surf the internet less than one hour, $20.4 \%$ use it two to three hours, and $11.2 \%$ spent three to four hours per day. An examination of this result showed that the findings were quite similar to the study conducted by Mokhtari et.al (2009) on a university in the USA, where a majority of the students enjoys using internet more than recreational reading, reading for academic purposes, or watching television.

Table 5. Hours spent on surfing internet

\begin{tabular}{lcc}
\hline \multicolumn{1}{c}{ Surfing internet } & $\begin{array}{c}\text { No. of } \\
\text { respondents }\end{array}$ & $\begin{array}{c}\text { Percentage } \\
(\%)\end{array}$ \\
\hline Less than 1 hour & 34 & 10.8 \\
\hline 1 to 2 hours & 181 & 57.6 \\
\hline 2 to 3 hours & 64 & 20.4 \\
\hline 3 to 4 hours & 35 & 11.2 \\
\hline
\end{tabular}

Table 6 shows the frequency or the number of books students have read during the last year (at the point of time of the questionnaire filling and interview). This study showed a majority of responding in the negative as to whether they had 
read a book/novel last year. A total of $70.4 \%$ declined that they had read a book or novel last year, and only $29.6 \%$ affirmed that they had read one or more book last year. This result showed Pandian's (1997b) thesis of 'reluctant reader' in Malay and in English and further confirmed that the average undergraduate students are perceived as such.

Table 6. Frequency of reading book/novel in year

\begin{tabular}{lcc}
\hline $\begin{array}{c}\text { Frequency of reading } \\
\text { book/novel }\end{array}$ & $\begin{array}{c}\text { No. of } \\
\text { respondents }\end{array}$ & $\begin{array}{c}\text { Percentage } \\
(\%)\end{array}$ \\
\hline Yes & 93 & 29.6 \\
\hline No & 221 & 70.4 \\
\hline
\end{tabular}

\subsection{Reading Attitudes}

According to the APA Dictionary of Psychology, (2015) attitude means, "a relatively enduring and general evaluation of an object, person, group, issue, or concept on a dimension ranging from negative to positive. Attitudes provide summary evaluations of target objects and are often assumed to be derived from specific beliefs, emotions, and past behaviours associated with those objects."

For the reading attitudes of the UMSKAL undergraduates, a 29 items questionnaire was used following the Adult Survey of Reading Attitude (ASRA) from the work of Smith (1991) and administered on 314 undergraduate students at UMSKAL. These 29 items are used with a 5-1 likert scale of which 11 items are on activity of reading, 9 items on enjoyment of reading, and 9 items on anxiety and difficulty in reading to measure out the students' attitudes and preferences towards reading. Averages were calculated from a scale of 5-1 (i.e. 5=Strongly Agree, 4=Agree, 3=Uncertain, 2=Disagree, $1=$ Strongly Disagree).

Table 7. Activity of reading

\begin{tabular}{|c|c|c|c|c|c|}
\hline QUESTION & $\begin{array}{l}\text { Strongly } \\
\text { Agree } \\
5\end{array}$ & Agree & Uncertain & Disagree & $\begin{array}{c}\text { Strongly } \\
\text { Disagree } \\
1\end{array}$ \\
\hline $\begin{array}{l}1 \text { I can read but I don't understand what I've } \\
\text { read. }\end{array}$ & $\begin{array}{c}62 \\
19.7 \%\end{array}$ & $\begin{array}{c}51 \\
16.2 \%\end{array}$ & $\begin{array}{c}69 \\
21.9 \%\end{array}$ & $\begin{array}{c}65 \\
20.7 \%\end{array}$ & $\begin{array}{c}67 \\
21.3 \%\end{array}$ \\
\hline $\begin{array}{l}2 \text { There are better ways to learn new things } \\
\text { than by reading a book. }\end{array}$ & $\begin{array}{c}56 \\
17.8 \%\end{array}$ & $\begin{array}{c}73 \\
23.2 \%\end{array}$ & $\begin{array}{c}82 \\
26.1 \%\end{array}$ & $\begin{array}{c}51 \\
16.2 \%\end{array}$ & $\begin{array}{c}52 \\
16.6 \%\end{array}$ \\
\hline 3 I am a good reader. & $\begin{array}{c}45 \\
14.3 \%\end{array}$ & $\begin{array}{c}39 \\
12.4 \%\end{array}$ & $\begin{array}{c}72 \\
22.9 \%\end{array}$ & $\begin{array}{c}56 \\
17.8 \%\end{array}$ & $\begin{array}{c}102 \\
32.5 \%\end{array}$ \\
\hline 4 When I am at home I read a lot. & $\begin{array}{c}47 \\
14.9 \%\end{array}$ & $\begin{array}{c}65 \\
20.7 \%\end{array}$ & $\begin{array}{c}78 \\
24.8 \%\end{array}$ & $\begin{array}{c}59 \\
18.8 \%\end{array}$ & $\begin{array}{c}65 \\
20.7 \%\end{array}$ \\
\hline 5 I want to have more books of my own. & $\begin{array}{c}58 \\
18.5 \%\end{array}$ & $\begin{array}{c}46 \\
14.6 \%\end{array}$ & $\begin{array}{c}71 \\
22.6 \%\end{array}$ & $\begin{array}{c}43 \\
13.7 \%\end{array}$ & $\begin{array}{c}96 \\
30.6 \%\end{array}$ \\
\hline $\begin{array}{l}6 \text { I try very hard, but I just can't read very } \\
\text { well. }\end{array}$ & $\begin{array}{c}62 \\
19.7 \%\end{array}$ & $\begin{array}{c}69 \\
21.9 \%\end{array}$ & $\begin{array}{c}73 \\
23.2 \%\end{array}$ & $\begin{array}{c}52 \\
16.6 \%\end{array}$ & $\begin{array}{c}58 \\
18.5 \%\end{array}$ \\
\hline $\begin{array}{l}7 \text { My friends and I often discuss the books } \\
\text { we have read. }\end{array}$ & $\begin{array}{c}52 \\
16.6 \%\end{array}$ & $\begin{array}{c}67 \\
21.3 \%\end{array}$ & $\begin{array}{c}88 \\
28.0 \%\end{array}$ & $\begin{array}{c}45 \\
14.3 \%\end{array}$ & $\begin{array}{c}62 \\
19.5 \%\end{array}$ \\
\hline $\begin{array}{l}8 \text { It is easier for me to understand what I am } \\
\text { reading if pictures, charts, and diagrams are } \\
\text { included. }\end{array}$ & $\begin{array}{c}136 \\
43.3 \%\end{array}$ & $\begin{array}{c}87 \\
27.7 \%\end{array}$ & $\begin{array}{c}43 \\
13.7 \%\end{array}$ & $\begin{array}{c}33 \\
10.5 \%\end{array}$ & $\begin{array}{c}15 \\
4.8 \%\end{array}$ \\
\hline 9 When I read I usually get tired and sleepy. & $\begin{array}{c}67 \\
21.3 \%\end{array}$ & $\begin{array}{c}63 \\
20.0 \%\end{array}$ & $\begin{array}{c}79 \\
25.2 \%\end{array}$ & $\begin{array}{c}57 \\
18.2 \%\end{array}$ & $\begin{array}{c}48 \\
15.3 \%\end{array}$ \\
\hline $\begin{array}{l}10 \text { I have a lot in common with people who } \\
\text { are poor readers. }\end{array}$ & $\begin{array}{c}89 \\
28.3 \%\end{array}$ & $\begin{array}{c}62 \\
19.7 \%\end{array}$ & $\begin{array}{c}59 \\
18.8 \%\end{array}$ & $\begin{array}{c}53 \\
16.9 \%\end{array}$ & $\begin{array}{c}51 \\
16.2 \%\end{array}$ \\
\hline 11 I spend a lot of my spare time reading. & $\begin{array}{c}45 \\
14.3 \%\end{array}$ & $\begin{array}{c}48 \\
15.3 \%\end{array}$ & $\begin{array}{c}78 \\
24.8 \%\end{array}$ & $\begin{array}{c}81 \\
25.8 \%\end{array}$ & $\begin{array}{c}62 \\
19.7 \%\end{array}$ \\
\hline
\end{tabular}

In table 7, question 1 to 11 shows varied types of reading activities and the respondents' attitude towards them. An average of $22.9 \%$ i.e. 72 respondents have shown their uncertain frame of minds which indicate that these undergraduate students were not sure about their involvement in various types of reading activities in the past and present. An average of $20.1 \%$ i.e. 62 respondents agreed to take part in various types of reading activities whereas an average of $18.4 \%$ disagreed i.e. 57 respondents were not into various types of reading activities at home or in the academic institutions in the past or in the present. In response to question 3, an average of $13.4 \%$ i.e. 42 respondents answered in a positive attitude, whereas an average of $25.2 \%$ i.e. 79 respondents answered in a negative attitude; while $22.9 \%$ i.e. 72 respondents showed uncertainty that borders on negative involvement in various types of reading activities. In a similar type of question 11, an average of $14.8 \%$ i.e. 46 respondents agreed that they spend a lot of their spare time reading, whereas $22.8 \%$ i.e. 71 respondents disagreed; while $24.8 \%$ i.e. 78 respondents expressed their uncertainty towards spending a good amount of their spare time in reading. This results shows that reading is not so favourite activities among these undergraduate students. 


\begin{tabular}{lccccc}
\hline \multicolumn{1}{c}{ QUESTION } & $\begin{array}{c}\text { Strongly } \\
\text { Agree }\end{array}$ & Agree & Uncertain & Disagree & $\begin{array}{c}\text { Strongly } \\
\text { Disagree }\end{array}$ \\
& 5 & 4 & 3 & 2 & 1 \\
\hline 12 Reading is one of the best ways for me & 56 & 55 & 93 & 67 & 43 \\
to learn things. & $17.8 \%$ & $17.5 \%$ & $29.6 \%$ & $21.3 \%$ & $13.7 \%$ \\
\hline 13 Reading is one of my favorite & 34 & 44 & 89 & 68 & 79 \\
activities. & $10.8 \%$ & $14.0 \%$ & $28.3 \%$ & $21.7 \%$ & $25.2 \%$ \\
& & & & & \\
\hline 14 I read when I have the time to enjoy it. & 53 & 73 & 84 & 46 & 58 \\
& $16.9 \%$ & $23.2 \%$ & $26.8 \%$ & $14.6 \%$ & $18.5 \%$ \\
\hline 15 I get a lot of enjoyment from reading. & 42 & 56 & 87 & 61 & 68 \\
& $13.4 \%$ & $17.8 \%$ & $27.7 \%$ & $19.4 \%$ & $21.7 \%$ \\
\hline 16 I like going to the library for books. & 63 & 52 & 56 & 61 & 82 \\
& $20.0 \%$ & $16.6 \%$ & $17.8 \%$ & $19.4 \%$ & $26.1 \%$ \\
\hline 17 When I read an interesting book, story, & 97 & 69 & 64 & 33 & 51 \\
or article I like to tell my friends about it. & $30.9 \%$ & $21.9 \%$ & $20.4 \%$ & $10.5 \%$ & $16.2 \%$ \\
\hline 18 Reading is one of the most interesting & 51 & 58 & 97 & 66 & 42 \\
things which I do. & $16.2 \%$ & $18.5 \%$ & $30.9 \%$ & $21.0 \%$ & $13.4 \%$ \\
\hline 19 I'm the kind of person who enjoys a & 50 & 58 & 94 & 67 & 45 \\
good book. & $15.9 \%$ & $18.5 \%$ & $29.9 \%$ & $21.3 \%$ & $14.3 \%$ \\
\hline 20 I enjoy receiving books as gifts. & 48 & 72 & 69 & 57 & 68 \\
& $15.3 \%$ & $22.9 \%$ & $21.9 \%$ & $17.8 \%$ & $21.7 \%$ \\
\hline
\end{tabular}

In table 8, question 12 to 20 shows the respondents' enjoyment of varied types of reading activities. An average of $25.9 \%$ i.e. 81 respondents have shown their uncertainty that is an indication that these undergraduate students were not in the frame of mind of enjoyment of various types of reading activities in the past and present. An average of $18.2 \%$ i.e. 56 respondents agreed that they did take part in various types of reading activities and enjoyed them whereas an average of $18.8 \%$ disagreed i.e. 58 respondents did not enjoy any types of reading activities at home or in the academic institutions in the past or in the present. In response to question 12, an average of $12.4 \%$ i.e. 39 respondents answered positively, whereas an average of $23.5 \%$ i.e. 73 respondents answered negatively; while $28.3 \%$ i.e. 89 respondents were uncertain whether or not reading were their favourite activities in the past or the present. In a similar type of question 14 , an average of $15.6 \%$ i.e. 49 respondents agreed that they enjoy reading, whereas $20.6 \%$ i.e. 64 respondents disagreed; while $27.7 \%$ i.e. 87 respondents were uncertain towards enjoyment from reading. In another question 17 , an average of $17.4 \%$ i.e. 54 respondents agreed, whereas an average of $17.2 \%$ i.e. 54 respondents disagreed; while $30.9 \%$ i.e. 97 respondents were uncertain whether or not reading were their one of the most interesting activities in the past or the present. This slightly negative attitude towards enjoyment of reading is an indication of these undergraduate students being perceived as 'reluctant reader' in Malay and in English as hypothesized by Pandian (1997b).

Table 9. Anxiety and difficulty in reading

\begin{tabular}{|c|c|c|c|c|c|}
\hline QUESTION & $\begin{array}{l}\text { Strongly } \\
\text { Agree } \\
5\end{array}$ & Agree & Uncertain & $\begin{array}{l}\text { Disagree } \\
2\end{array}$ & $\begin{array}{c}\text { Strongly } \\
\text { Disagree } \\
1\end{array}$ \\
\hline 21 I need a lot of help in reading. & $\begin{array}{c}117 \\
37.3 \%\end{array}$ & $\begin{array}{c}59 \\
18.8 \%\end{array}$ & $\begin{array}{c}54 \\
17.2 \% \\
\end{array}$ & $\begin{array}{c}45 \\
14.3 \%\end{array}$ & $\begin{array}{c}39 \\
12.4 \%\end{array}$ \\
\hline $\begin{array}{l}22 \text { I get upset when I think about having to } \\
\text { read. }\end{array}$ & $\begin{array}{c}62 \\
19.7 \% \\
\end{array}$ & $\begin{array}{c}65 \\
20.7 \% \\
\end{array}$ & $\begin{array}{c}72 \\
22.9 \% \\
\end{array}$ & $\begin{array}{c}56 \\
17.8 \% \\
\end{array}$ & $\begin{array}{c}59 \\
18.8 \% \\
\end{array}$ \\
\hline $\begin{array}{l}23 \text { I often feel anxious when I have a lot of } \\
\text { reading to do. }\end{array}$ & $\begin{array}{c}112 \\
35.7 \%\end{array}$ & $\begin{array}{c}73 \\
23.2 \%\end{array}$ & $\begin{array}{c}42 \\
13.4 \%\end{array}$ & $\begin{array}{c}37 \\
11.8 \%\end{array}$ & $\begin{array}{c}50 \\
15.9 \%\end{array}$ \\
\hline $\begin{array}{l}24 \text { I get nervous if I have to read a lot of } \\
\text { information for my job or for some social } \\
\text { activity. }\end{array}$ & $\begin{array}{c}94 \\
29.9 \%\end{array}$ & $\begin{array}{c}76 \\
24.2 \%\end{array}$ & $\begin{array}{c}62 \\
19.7 \%\end{array}$ & $\begin{array}{c}35 \\
11.1 \%\end{array}$ & $\begin{array}{c}47 \\
14.9 \%\end{array}$ \\
\hline $\begin{array}{l}25 \text { Encountering unfamiliar words is the } \\
\text { hardest part of reading. }\end{array}$ & $\begin{array}{c}135 \\
42.9 \%\end{array}$ & $\begin{array}{c}71 \\
22.6 \%\end{array}$ & $\begin{array}{c}47 \\
14.9 \%\end{array}$ & $\begin{array}{c}20 \\
6.4 \%\end{array}$ & $\begin{array}{c}41 \\
13.0 \%\end{array}$ \\
\hline 26 I worry a lot about my reading. & $\begin{array}{c}117 \\
37.3 \% \\
\end{array}$ & $\begin{array}{c}77 \\
24.5 \% \\
\end{array}$ & $\begin{array}{c}58 \\
18.5 \% \\
\end{array}$ & $\begin{array}{c}35 \\
11.1 \% \\
\end{array}$ & $\begin{array}{c}27 \\
8.6 \% \\
\end{array}$ \\
\hline $\begin{array}{l}27 \text { I try to avoid reading because it makes } \\
\text { me feel anxious. }\end{array}$ & $\begin{array}{c}97 \\
30.9 \% \\
\end{array}$ & $\begin{array}{c}69 \\
21.9 \%\end{array}$ & $\begin{array}{c}47 \\
14.9 \% \\
\end{array}$ & $\begin{array}{c}49 \\
15.6 \%\end{array}$ & $\begin{array}{c}52 \\
16.6 \%\end{array}$ \\
\hline 28 I have trouble understanding what I read. & $\begin{array}{c}64 \\
20.4 \%\end{array}$ & $\begin{array}{c}69 \\
21.9 \%\end{array}$ & $\begin{array}{c}82 \\
26.1 \%\end{array}$ & $\begin{array}{c}56 \\
17.8 \%\end{array}$ & $\begin{array}{c}43 \\
13.7 \%\end{array}$ \\
\hline $\begin{array}{l}29 \text { I'm afraid that people may find out what } \\
\text { a poor reader I am. }\end{array}$ & $\begin{array}{c}52 \\
16.6 \% \\
\end{array}$ & $\begin{array}{c}57 \\
18.2 \% \\
\end{array}$ & $\begin{array}{c}108 \\
34.4 \% \\
\end{array}$ & $\begin{array}{c}50 \\
15.9 \% \\
\end{array}$ & $\begin{array}{c}47 \\
14.9 \% \\
\end{array}$ \\
\hline
\end{tabular}


In Table 9 question 21 to 29 shows the respondents' anxiety and difficulty in varied types of reading activities. An average of $20.2 \%$ i.e. 63 respondents have shown uncertainty regarding these undergraduate students level of anxiety and difficulty in various types of reading activities in the past and present. An average of $25.9 \%$ i.e. 81 respondents agreed whereas an average of $13.9 \%$ i.e. 43 respondents disagreed that they had anxiety and difficulties in various types of reading activities at home or in the academic institutions in the past or in the present. In response to question 23 , an average of $29.5 \%$ i.e. 92 respondents answered positively, whereas an average of $13.9 \%$ i.e. 43 respondents answered negatively; while $13.4 \%$ i.e. 42 respondents were uncertain whether or not they were anxious while they had to do a lot of reading in the past or the present. In a similar type of question 26, an average of $30.9 \%$ i.e. 97 respondents agreed, whereas $9.9 \%$ i.e. 31 respondents disagreed; while $18.5 \%$ i.e. 58 respondents were uncertain whether or not they worried a lot about reading. In another question 27 , an average of $26.4 \%$ i.e. 83 respondents agreed, whereas an average of $16.1 \%$ i.e. 50 respondents disagreed; while $14.9 \%$ i.e. 47 respondents were uncertain whether or not they tried to avoid reading because it made them feel anxious. In table 8 , the finding showed that these undergraduate students did enjoy reading although not to a great extent (an average of $18.2 \%$ liking to $18.8 \%$ disliking). This is reflected in the resulting anxieties and difficulties in reading found from the outcomes in table 9.

Table 10. Overall percentage of reading attitudes

\begin{tabular}{lccc}
\hline \multicolumn{1}{c}{ Variables } & Agree & Uncertain & Disagree \\
& & & \\
\hline Activity of reading & 125 & 72 & 115 \\
& $40.2 \%$ & $22.9 \%$ & $36.8 \%$ \\
\hline Enjoyment of reading & 113 & 81 & 117 \\
& $36.4 \%$ & $25.9 \%$ & $37.5 \%$ \\
\hline Anxiety and difficulty in & 162 & 63 & 87 \\
reading & $51.8 \%$ & $20.2 \%$ & $27.8 \%$ \\
\hline
\end{tabular}

In Table 10, we get an overall picture of the respondents' attitudes towards reading in terms of the participants' activity in reading, enjoyment of reading, and their anxiety and difficulty in reading.

While engaged in various types of reading activities, $40.2 \%$ i.e. 125 respondents answered in a positive way, whereas $36.8 \%$ i.e. 115 respondents answered negatively, and $22.9 \%$ i.e. 72 respondents were uncertain about their involvements in such types of activities. With response to the enjoyment of reading, 36.4\% i.e. 113 respondents agreed, whereas a marginal $37.5 \%$ i.e. 117 respondents disagreed while $25.9 \%$ i.e. 81 respondents were uncertain about their enjoyment of such activities. The cumulative effects of the anxieties and difficulties of reading among these participants were evident as $51.8 \%$ i.e. 162 respondents agreed, whereas $27.8 \%$ i.e. 87 respondents disagreed, while $20.2 \%$ i.e. 63 respondents were uncertain. From the above findings we may conclude that these undergraduate students' involvement into various types of reading activities bordered on the negative as they enjoyed it rather nominally and due to that they faced anxieties and difficulties while engaged in reading academic or non-academic materials.

If that is an indication, the following selected comments made by the respondents reflect an overall positive frame of mind of these undergraduate students in spite of their proper lack of practice and enjoyment of reading.

"I think reading is crucial in life because it is use worldwide".

"Reading is important but I'm lazy to read because it's boring".

"Reading is like a journey. The more you read, the more knowledge you get".

"I like reading in English because it will help me to be a knowledgeable person and help me to study another subject".

"Reading in English is boring, I tend to listening in English".

"Reading in English is interesting, but reading in Chinese is more interesting for me".

"Reading is the best action for me to make me understand a lot of knowledge in world. I love to read in Malay, Arab and English because it is to make me think matured".

"Reading is very important in our daily life. It can help me improve the comprehension of articles and broaden my horizon. It is really useful to get more information in this modern time".

"I feel that reading in English is very important in order to success in life".

"To be honest, I'm not really into reading. But its not a bad thing, so in the positive way, reading can help me improve my knowledge and add more my vocabulary. No pain, no gain”.

"I like to read in English. Sometimes depends on my mood".

"Not good enough in English? READ more".

\section{Implications of the Analysis}

This study was undertaken with a view to measure out the reading habits and attitudes of undergraduate students at a public university in Malaysia. From the first six open-ended questions, it was found that majority of the students use internet and watches television rather than read during spare time. These students' spent an average of 1-2 hours per day reading academic books rather than using other recreational reading materials such as newspapers, fictions etc. The study also showed that the materials used per day by these students were mostly online materials, and the majority of students prefer to read in Malay and only $18.5 \%$ students use English reading materials. From this study it was also found that a majority of students spent a significant amount of time in surfing internet. This finding corroborate with 
other studies done by Mokhtari et.al (2009), Pandian (1999), Subashini and Balakrishnan (2013). While this phenomenon is quite common and alarming from the point of view for these learners, Iftanti (2015) in her study of student's good reading habits contends that internet could be a contributory factor in establishment of ESL students' good English reading habits since the electronic media have nearly limitless access to searchable information and ebooks and such other materials. In response to the reading in a year year, majority of the respondents answered in the negative and this indicates that these students on average are reluctant ESL readers.

In response to their attitudes the findings showed that reading was not so favourite among these undergraduates; their enjoyment of it was nominal, and therefore, they face anxiety and difficulties in ESL reading activities. Yet one quite contradictory fact remains to be taken into account here is that even though the participants' reading habits, preferences and the enjoyment of it were not so favourable and encouraging, yet their overall attitude towards reading is quite positive as have been evidenced from students' comment from the interview. The overall picture from this study shows that these undergraduate students are lacking in proper/appropriate practice of reading. This is a common phenomenon in the educational institutes throughout the country. They face difficulty with the other three skills, namely, speaking, listening and writing due to this lack of proper reading habits which ultimately downgrade their overall level of proficiency in English.

\section{Conclusion and Recommendations}

This current study was initiated with a view to discern the prevailing condition of reading habits and attitudes of the undergraduate students at a public university in Malaysia. Findings from this study showed that in spite of an overall positive attitude towards reading, these students seriously lack a proper reading habit and practice both in and outside the classroom, i.e. intensive and extensive reading. This lack of appropriate and adequate practice of reading among the undergraduates were ingrained from a very early stage due to many socio-cultural, socio-economic and socio psychological factors as had been substantiated by Pandian (1997a, 1997b).

We as language teachers have to play vital and manifold roles (such as role model, facilitator/councillor, motivator etc.) in order to motivate and instill interests for both intensive and extensive reading in our students. Both parents and the community also have their own role to play in this situation. To dispel the label 'reluctant readers', we have to develop a positive attitude towards reading among these students with activities replete with fun and a means of lifelong learning. Various types of promotional activities like book clubs, book fairs and book promotions could be advocated. Also, a certain amount of time per week can be allocated for the students and teachers to read for pleasure in the classroom. Furthermore, to facilitate and further improve the ESL reading skills among the students, an amalgamation of appropriate teaching approaches or methodologies can be adapted and practiced in the reading classrooms.

This current study was confined to find out the prevailing reading habits and attitudes of these students at the tertiary level. It is a much bigger picture that deserves more comprehensive and thorough look for further development. Moreover, the findings of this study were limited to one particular public university in Labuan, Malaysia only. Supplementary studies could be done to focus on various other factors that encumber and influence these tertiary level students' lack of proper reading habits and ways to improve their enjoyment and involvement in reading as a whole. Teachers, educators and authorities should take into account this prevailing condition of tertiary level students' reluctancy in reading that is so common and familiar in educational institutes throughout Malaysia and come up with some significant and effective solution to it.

Concerted efforts from teachers, parents and the community have to play a more active role in propagating and encouraging the habit of reading among the younger generations. Keeping pace with the rapid advancements and changes in society, economy, and technology is going to be a great challenge for all in $21^{\text {st }}$ century. In this context Pandian (1999) anticipates that "While Malaysia is trying to propel the people into the front-line of the global information age, it is important that to ensure that the education that students experience will enable them to negotiate activity with a variety of texts in print, visual and electric forms. It is also essential that the family, the school and the wider community share a common responsibility for preparing young people for a life in which mediated knowledge, information and entertainment will increasingly play a major role in shaping their ideas, beliefs, values, choices and decisions".

\section{Acknowledgements}

The researcher expresses profound thankfulness for the photocopying support from PPIB, KAL and to the participating students for their time and invaluable comments/suggestions related to this study.

\section{Reference}

Ahmed, S. (2015). Attitudes towards English Language Learning among EFL Learners at UMSKAL. Journal of Education and Practice, Vol. 6 No. 18, 6-16.

Akanda, A.K.M. E.A., Hoq, K.M.G. \& Hasan, N. (2013). Reading Habit of Students in Social Sciences and Arts: A Case Study of Rajshahi University. Chinese Librarianship: an International Electronic Journal, 35. Retrieved from http://www.iclc.us/cliej/c135AHH.pdf

Akarsu, O. \& Dariyemez, T. (2014). The reading habits of university students studying English language and literature in the digital age. Journal of Language and Linguistic Studies, 10(2), 85-99. 
Anderson, N. J. (2012). Reading instruction. In J. Richards and A. Burns (Eds.). Cambridge Guide to Pedagogy and Practice in Language Teaching (pp. 218-225). Cambridge, UK: Cambridge University Press.

APA Dictionary of Psychology. (2015). G.R. VandenBos (2nd Ed.). Washington, DC: American Psychological Association.

Bendriss, R. \& Golkowska, K. (2011). Early Reading Habits and their Impact on the Reading Literacy of Qatari Undergraduate Students. Arab World English Journal, Vol.2 No. 4, 37-57.

Crystal, D. (2008). A Dictionary of Linguistics and Phonetics (6th Ed.). USA: Blackwell Publishing.

Don, F. H. \& Osman, S. (1987). Reading and National Development: What the Universities Can Do. The English

Teacher, Vol. XVI, 73-74. Retrieved from http://www.melta.org.my/ET/1987/main6.html

Dörnyei, Z. \& Taguchi, T. (2010). Questionnaires in Second Language Research: Construction, Administration, and Processing (2nd Ed.). UK: Routledge.

English, S. (2011). Strategy intervention and reading proficiency in the modern tertiary EFL classroom. Retrieved from http://www.nyu.edu/classes/keefer/waoe/englishs.html.

Grabe, W. (2009). Reading in a Second Language: Moving from Theory to Practice. Cambridge: Cambridge University Press.

Grabe, W. \& Stoller, F.L. (2013). Teaching and Researching Reading (2nd Edition). UK: Routledge.

Guthrie, J.T. \& Wigfield, A. (2000). Engagement and motivation in reading. In M.L. Kamil, P.B. Mosenthal, P.D. Pearson and R. Barr (Eds.). Handbook on reading research (pp. 403-422). Mahwah, NJ: Erlbaum.

Harmer, J. (1998). How to teach English. NY: Longman ELT.

Iftanti, E. (2015). What makes EFL students establish Good Reading Habits in English? International Journal of Education and Research, Vol. 3, No. 5, 365-374.

Inderjit, S. (2014). Reading Trends and Improving Reading Skills among Students in Malaysia. International Journal of Research in Social Sciences, Vol.3, No.5, 70-81.

Ismail, N. \& Elias, S. (2009). An Analysis of the Reading Attitudes and Habits among ESL Part One Diploma Students in MARA, University of Technology Malaysia, Johor Branch. The International Journal of Interdisciplinary Social Sciences, Vol. 4, No. 8, 181-190.

Jadal, M.M. (2013). Study of the Reading Habits of the B.Ed. Students. Indian Streams Research Journal, Volume 3, Issue. $1,1-11$

Karim, A., Hasan A., \& Shahriza, N. (2007). Reading habits and attitude in the digital age: Analysis of gender and academic program differences in Malaysia. The Electronic Library, Vol. 25 Issue: 3, 285-298.

Koda, K. (2008). Insights into Second Language Reading: A Cross-Linguistic Approach. UK: Cambridge University Press.

Kumar, C.R. (2008). Research Methodology. New Delhi: APH Publishing Corporation.

Kwong, C.E., Othman, H. \& Rajeswari, P.D. (2005). A survey of the reading habits among UiTM Perlis undergraduate students. Universiti Teknologi MARA. Retrieved from http://ir.uitm.edu.my/6705/

Mackey, A. \& Gass, S.M. (2005). Second Language Research: Methodology and Design. Mahwah, New Jersey: Lawrence Erlbaum Associates, Inc.

McDonough, J. \& McDonough, S. (1997). Research Methods for English Language Teachers. London: Hodder Education.

McKay, S.L. (2006). Researching Second Language Classrooms. Mahwah, N.J.: Lawrence Erlbaum Associates.

Mikulecky, B. S. (2008). Teaching Reading in a Second Language. Pearson Education. http://longmanhomeusa.com/content/FINAL-LO\%20RES-Mikulecky-Reading\%20Monograph.pdf

Mokhtari, K. \& Sheorey, R. (1994). Reading habits of university ESL students at different levels of English proficiency and education. Journal of Research in Reading, 17(1), 46-61.

Mokhtari, K., Reichard, C.A., \& Gardner, A. (2009). The Impact of Internet and Television Use on the Reading Habits and Practices of College Students. Journal of Adolescent and Literacy, 52(7), 609-619.

Mullai, R. (2001). Literacy: State of the Art at the Tertiary Level. Journal of Modern Languages, Vol. 13, Issue 1, 93105 .

Murray, D.E. \& Christison, M.A. (2010). What English Language Teachers Need to Know. Volume I, Understanding Learning. UK: Taylor \& Francis e-Library.

Noor, N. M. (2011). Reading habits and preference of EFL post graduates: A case study. Conaplin Journal: Indonesian Journal of Applied Linguistics, 1(1), 1-8.

Nunan, D. (1992). Research Methods in Language Learning. Cambridge: Cambridge University Press.

Pandian, A. (1997a). Post-Colonial Literacy in Malaysia. International Journal of Adolescent and Adult Literacy.

Pandian, A. (1997b). Reading in Malaysia. Kuala Lumpur: Bangi: UKM. 
Pandian, A. (1999). Whither Reading in Malaysia: Confronting Reading Reluctancy among Pre-university Students. Global Literacy - Vision, Revision and Vistas in Education, ed. Ambigapathy Pandian, Universiti Putra Malaysia Press, Serdang.

Richards, J. C., \& Schmidt, R. (2010). Longman dictionary of language teaching and applied linguistics (4th Ed.).

London: Longman (Pearson Education).

Sidek, H.M. (2011). Methods of EFL Secondary Reading Instruction: Preparation for Higher Education. International Journal of Humanities and Social Science, 1(3), 181-191.

Smith, M.C. (1991). An investigation of the construct validity of the adult survey of reading attitude. Paper presented at the annual meeting of the College Reading Association, Alexandria, VA. Available at: www.cedu.niu.edu/,smith/papers/asra.htm

Stoller, F. L., Anderson, N. J., Grabe, W., \& Komiyama, R. (2013). Instructional Enhancements to Improve Students' Reading Abilities. English Teaching Forum, 51(1), 2-11.

Subashini, A. \& Balakrishnan, M. (2013). Reading Habit and Attitude among Malaysian Polytechnic Students. International Online Journal of Educational Sciences, 5(1), pp. 32-41.

Susana, L. \& Mathai, E. J. (2003). Reading Attitudes of UiTM Penang Students: An Exploratory Study. ESTEEM, Vol. 1, 109-120.

Tavakoli, H. (2012). A Dictionary of Research Methodology and Statistics in Applied Linguistics. Tehran, Iran: Rahnama Press.

Tindale, J. (2003). Teaching Reading. National Centre for English Language Teaching and Research. Sydney: Macquarie University.

Wallace, C. (2003). Reading. Oxford: Oxford University Press. 